\title{
The taxonomy and phylogeography of Palaearctic true lemmings (Lemmus, Cricetidae, Rodentia): New insights from cyt $b$ data
}

\author{
Natalya I. Abramson, Alexei Yu. Kostygov \& Ekaterina N. Rodchenkova
}

\begin{abstract}
New data that significantly specified phylogeography and taxonomic structure of Palearctic lemmings (Lemmus) have been obtained. Therewith, the data on nucleotide composition of cyt $b$ in true lemmings from the Lena River mouth, the terra typica for L. sibiricus bungei were of particular significance. It has been shown that 1) results are highly reproducible; 2) new, for the first time studied samples from the mouth of the Lena River undoubtedly referred to the west clade and thus, its border shifts to the east; 3 ) distinguishing of the distinct species L. bungei is not supported by morphological, biological, and molecular data as far as terra typica is inhabited by lemmings referring to the clade of typical L. sibiricus. New data on the variation of cyt $b$ are in a good agreement with morphological, paleontological, and zoogeographical data. They better fit the taxonomic division of the genus.
\end{abstract}

KEY WORDS: Lemmus, phylogeography, cytochrome $b$, taxonomy.

Nataliya I.Abramson [lemmus@zin.ru], AlexeiYu.Kostygov [akostygov@gmail.com], and Ekaterina N.Rodchenkova [katu1985@mail.ru],Zoological Institute, Russian Academy of Science, Universitetskaya nab. 1, St.Petersburg 199034, Russia.

\section{Таксономия и филогеография настоящих леммингов Палеарктики (Lemmus, Cricetidae, Rodentia): новые данные по изменчивости цитохрома $b$}

\author{
Н.И. Абрамсон, А.Ю. Костыгов, Е.Н. Родченкова
}

\begin{abstract}
РЕЗЮМЕ. Получены новые оригинальные данные, значительно уточнившие филогеографию и таксономическую структуру палеарктических представителей рода Lemmus. Решающее значение, при этом, имели полученные данные секвенирования цитохрома $\sigma$ у настоящих леммингов с о-вов дельты р. Лены - terra typica L. sibiricus bungei. Анализ показал 1) высокую воспроизводимость результатов: наши материалы с Камчатки и с Кольского п-ова точно кластеризуются с образцами из этих регионов, изученными ранее; 2) новые, ранее неизученные образцы из дельты р. Лены вне всякого сомнения относятся к западной филогеографической кладе, и таким образом ее граница смещается на восток; 3) выделение вида L. bungei не только не подкреплено данными морфологии и биологии, но и молекулярными данными, так как terra typica заселена леммингами, без сомнения относящимися к кладе типичных L. sibiricus. Новые данные по изменчивости цитохрома б лучше согласуются как с морфологическими, палеонтологическими и зоогеографическими данными, также и с существующей таксономической схемой рода.
\end{abstract}

КЛЮЧЕВЫЕ СЛОВА: Lemmus, филогеография, цитохром б, таксономия, Палеарктика.

\section{Introduction}

The taxonomy of the genus Lemmus Link 1795 is not stable and was fundamentally revised several times during the $20^{\text {th }}$ century. These revisions were dependant of species concepts, methods applied, and sometimes just because of an author's personal fancy to split or combine species. Three stages can be distinguished in the studies of lemming taxonomy based on the methods used. The first stage (1920s- mid 70s) of research was based on analyses of variation in fur color, body measurements, and some cranial characteristics (e.g., Vinogradov, 1925; Ognev, 1948; Krivosheev \& Rossolimo, 1966). The results were controversial: the number of species varied from two to five with different number of subspecies recognized. An extreme point of view that has not received recognition was formulated by Sidorowicz (1964), who believed in the existence of a single polytypic species L. lemmus L., 1758 with three subspecies.

The second stage (mid 70s - end of 80s) was related to the application of cytogenetic methods and experimental hybridization (Rausch \& Rausch, 1975; Pokrovskii et al., 1984; Gileva et al., 1984). The main and most striking result of these studies was that there were not the expected profound genetic differences between generally recognized "good species" - Norwegian ( $L$. lemmus), Siberian (L. sibiricus Kerr, 1792), and Amur (L. amurensis Vinogradov, 1924) lemmings, nor be- 
tween true lemmings of the New and Old World. Lemmings from the Chukotka Peninsula had a karyotype identical to North American L. trimucronatus Richardson, 1825, but were different from all other Eurasian lemmings ( $L$.lemmus, L. amurensis and L. sibiricus, including $L$. s. portenkoi from Wrangel Island and $L$. $s$. flavescens from Kamchatka) in karyotype and having reproductive isolation. All the latter forms hybridized readily in experiments and have an identical karyotype (Pokrovskii et al., 1984). Subsequent research had shown that there is a boundary between the two karyological forms along the Kolyma River (Fredga et al., 1999). However the proposal to consider the genus as containing two species, L. trimucronatus and polytypic $L$. lemmus (Kuznetsova, 1995) did not receive support, and the current practice of most reviewers continues to split the genus into three (L. lemmus, L. sibiricus, and $L$. amurensis - Musser \& Carleton, 1993), four (L. lemmus, L. sibiricus, L. amurensis, and L. trimucronatus — Jarell \& Fredga, 1993; Gromov \& Erbajeva, 1995; Pavlinov, 2006), or five separate species (Musser \& Carleton, 2005: L. portenkoi Chernyavskii, 1967 from Wrangel Island considered as an independent species).

The novelty of the latest stage studies (i.e. through 1990s, by Chernyavskii et al., 1993; Abramson, 1999a, b; Fedorov et al., 1999; Fredga et al., 1999) is related to the attempts to synthesize data from paleontology, paleogeography, cytogenetics, classical morphology, and finally, the analysis of mtDNA variation together with obtaining additional material from poorly surveyed regions of the Arctic. These studies have shown, in particular, that lemmings from Wrangel Island, Kamchatka Peninsula, and Amur lemmings, despite substantial differences in size and fur color, share characteristics of dentition and skull and jaw proportions with true lemmings of the Late Pleistocene (Chernyavskii et al., 1993). Interestingly the relatedness of these forms was later confirmed by the analysis of nucleotide variation in the cytochrome $b$ (Fedorov et al., 1999). Molecular data also confirmed the previous results of cytogenetic and hybridization studies in demonstrating the large genetic divergence between $L$. trimucronatus from Chukotka and Alaska and other Eurasian true lemmings. The application of molecular - genetic data to the same material has revealed genetic separation of continental Palaearctic populations of $L$. sibiricus into western and eastern groups with the boundary putatively along the Lena River (Abramson, 1999a; Fedorov et al., 1999). In this case the genetic distance was the next largest after that between L. trimucronatius and Eurasian true lemmings, while the level of morphological differences was low. This separation previously was not reflected in lemming taxonomy, and resurrected the subspecies L. sibiricus bungei Vinogradov, 1925 described from the Lena River delta which failed to receive recognition. Some authors (Fredga et al., 1999; Shenbrot \& Krasnov, 2005) assigned most importance to differences obtained by analyses of mtDNA and consider L. bungei to be a separate species, and thus distinguish five species within the genus. The morphological characteristics, however, favor its status only as a subspecies, while making inferences for taxonomy directly from quantitative evaluation of a fragment of one molecular marker is bound to a serious bias (Hendry at al., 2000; Nichols, 2001; Abramson, 2007). In addition, and the most important argument against elevation of $L$. bungei to species level was that material from the Lena River delta (terra typica of L. s. bungei) was not studied. In the current paper we aimed first to analyze the lemmings from the terra typica of $L$. $s$. bungei using molecular marker cytochrom $b$ and to assign it to any known lemming phylogroup (Fedorov et al., 1999, 2003) and to clarify the debatable question in Lemmus taxonomy. Secondly we add some additional sampling to specify lemming phylogeography.

\section{Material and methods}

Samples and DNA extraction. Samples were provided by individuals or were collected during the Swedish-Russian expedition in the summer 2002 on Kola Peninsula and during Russian-German expedition "Lena delta 2001" in the summer of 2001 (Tab. 1). Total genomic DNA was extracted from ethanol preserved muscles, kidney or liver using proteinase K digestion, precipitation of proteins with phenol/chloroform and DNA precipitation with ethanol (Sambrook et al., 1989).

PCR amplification and sequencing. Partial segments of cytochrome $b$ (cyt $b$ ) gene $(662 \mathrm{bp})$ were amplified by the polymerase chain reaction (PCR). The PCR included an initial $5 \mathrm{~min}$ denaturation step, 30 cycles of alternating denaturation at $95^{\circ} \mathrm{C}$ for $30 \mathrm{sec}-$ onds, annealing at $55^{\circ} \mathrm{C}$ for 30 seconds, extension at $72^{\circ} \mathrm{C}$ for 45 seconds and a final 5 min extension step at $72^{\circ} \mathrm{C}$. Specially designed pair of primers, specific for genus Lemmus, were used both for amplification and sequencing: 5'TCGGATCCCTCCTAGGACTT/5'GT GGATTTGCTGGGGTGTAA. Amplifications were performed in $50 \mu \mathrm{L}$ reaction volumes with the following reagents and concentrations: primers ( $1 \mu \mathrm{M}$ each), dNTP $(0.2 \mathrm{mM}), \mathrm{MgCl}_{2}(1.5 \mathrm{mM}) 10 \mathrm{x}$ Tag buffer and Tag polymerase (Helicon) in a GenAmp PCR system 2700 (Applied Biosystems). All PCR experiments included negative control. PCR products were visualized on $1.5 \%$ agarose gel and then purified using Qiagen QIAquick kit. Approximately 10-30 ng of the purified PCR product was used for sequencing with each primer by autosequencing system 3730 DNA Analyzer (Applied Biosystems, Foster City, CA, USA) using ABI PRISM ${ }^{\circledR}$ BigDye $^{\text {TM }}$ Terminator v. 3.1. Sequences were aligned and compared manually using the Bioedit v.7.0.3 (Hall, 1999).

Data analyses. Estimates of divergence between haplotypes were calculated by using Kimura's two parameter method, and a neighbor-joining (NJ) phylogenetic tree (Saitou \& Nei, 1987). Phylogenetic and molecular evolutionary analyses were conducted using MEGA version 4 (Tamura et al., 2007). 
Table 1

Map references, geographical locations, abbreviations, collection numbers and GenBank Accession numbers of Lemmus haplotypes used in this study.

\begin{tabular}{|c|c|c|c|c|c|}
\hline $\begin{array}{l}\text { Map } \\
\text { ref. }\end{array}$ & Geographic origin & abbreviations & $\begin{array}{c}\mathrm{N} \text { in tissue and } \\
\text { DNA collection ZIN } \\
\text { RAS }\end{array}$ & $\begin{array}{c}\text { GenBank accession } \\
\text { numbers }\end{array}$ & Reference \\
\hline \multicolumn{6}{|c|}{ Leтmиs leтmиs } \\
\hline 1 & Kola Peninsula, Ponoi & L11 & & AY219145 & Fedorov et al., 2003 \\
\hline 2 & Finland & L11416 & & AF348392 & Fedorov \& Stenseth, 2001 \\
\hline 3 & Sweden, Vasterbotten, Ammarnas & & 385 & FJ025984 & Current study \\
\hline 4 & Kola Peninsula, center & & 395 & FJ025985 & Current study \\
\hline \multicolumn{6}{|c|}{ Lemmus sibiricus } \\
\hline 5 & West Yamal & Ls12 & & AJ012671 & Fedorov et al., 1999 \\
\hline 5 & West Yamal & Ls 14 & & AF348390 & Fedorov \& Stenseth, 2001 \\
\hline 5 & West Yamal & Ls2 & & AF348389 & Fedorov et al., 2003 \\
\hline 6 & North Yamal & & 391 & FJ025986 & Current study \\
\hline 7 & North-Western Taymyr & Ls 5 & & AY219140 & Fedorov et al., 2003 \\
\hline 8 & North-Eastern Taymyr & Ls 4 & & AY219143 & Fedorov et al., 2003 \\
\hline 9 & Olenekskiy Bay & Ls26 & & AJ012672 & Fedorov et al., 1999 \\
\hline 10 & $\begin{array}{l}\text { Lena Delta, Samoilovskii isl., terra } \\
\text { typica L.s.bungei }\end{array}$ & & 371,373 & $\begin{array}{l}\text { FJ025980 } \\
\text { FJ025981 }\end{array}$ & Current study \\
\hline 11 & Indigirka Delta & Ls 7 & & AJ012673 & Fedorov et al., 1999 \\
\hline 12 & West bank of Kolyma & Ls 6 & & AY219144 & Fedorov et al., 2003 \\
\hline 13 & Kotelnyi Island & Ls10 & & AY219141 & Fedorov et al., 2003 \\
\hline 14 & Fadeyevskiy Island & Ls9 & & AY219142 & Fedorov et al., 2003 \\
\hline 15 & South-Western Wrangel Island & Ls30 & & AJ012677 & Fedorov et al., 1999 \\
\hline 16 & Kamchatka, Uzon & Ls34 & & AJ012678 & Fedorov et al., 1999 \\
\hline 16 & Kamchatka, Uzon & & $396,399,397$ & $\begin{array}{c}\text { FJ025979, } \\
\text { FJ025977, FJ025978 }\end{array}$ & Current study \\
\hline \multicolumn{6}{|c|}{ Lemmus trimucronatus } \\
\hline 17 & East of Kolyma Delta & Lt2 & & AJ012675 & Fedorov et al., 1999 \\
\hline \multirow[t]{5}{*}{18} & Chukotka Peninsula, North of Anadyr & & 377,378 & $\begin{array}{l}\text { FJ025982 } \\
\text { FJ025983 }\end{array}$ & Current study \\
\hline & West Alaska* & Lt8 & & AJ012676 & Fedorov et al., 1999 \\
\hline & Alaska, Goodnews Bay* & Lt22 & & AY219153 & Fedorov et al., 2003 \\
\hline & Alaska, Seward Peninsula* & Lt24 & & AY219146 & Fedorov et al., 2003 \\
\hline & St.George Island, Alaska* & Lt25 & & AY219164 & Fedorov et al., 2003 \\
\hline
\end{tabular}

* Localities in Alaska most close to the Bering Strait are not shown on the map.

\section{Results and discussion}

For the cyt $b$ sequences, a total of 662 bp were scored, among which 109 sites were variable and 95 were parsimony informative. There were 28 different cyt $b$ haplotypes among 28 lemmings. The neighbourjoining tree (Fig. 2) generally confirm the earlier results (Fedorov et al., 1999, 2003) showing the main phylogenetic division across the Kolyma River, but net diver- gence with addition of our material became higher $10.5 \% \pm 1 \%$ (SE). This split in mitochondrial DNA coincides with a conventionally recognized and reproductively isolated species: Palaearctic L. sibiricus and Nearctic L. trimucronatus. Our data also confirmed the previously known second large split with a net divergence in $4.4 \pm 0.9 \%$ (SE) within L. sibiricus proper, which conditionally divides the populations of this species into a western and eastern phylogroup. However, if 


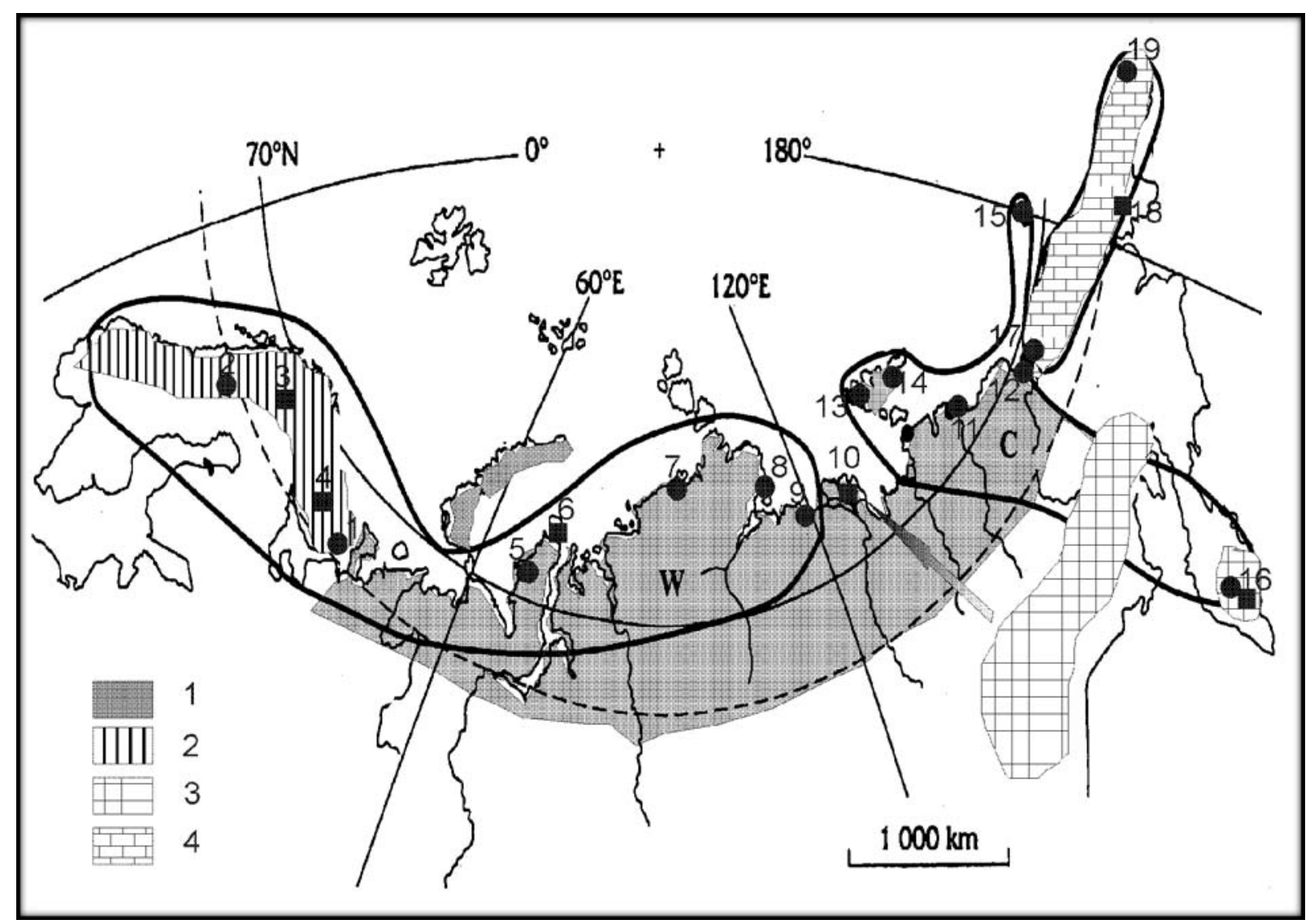

Figure 1. The map showing the recent distribution of L. sibiricus (1), L. lemmus (2), L.amurensis (3) and L. trimucronatus (4). Black circles show the geographic locations of sites from where specimens were sequenced earlier (Fedorov et al., 1999) numbers designated as in Fedorov et al., 2003 and black squares show the localities with specimens sequenced in this study (see Table 1). Black lines contour the geographic distribution of the main mtDNA clades according to Fedorov (1999), arrow point on "terra typica" of L. s. bungei.

earlier the geographical border between these phylogroups thought to be across the Lena River (Fedorov et al., 1999, 2003; Fredga et al., 1999) the results presented here clearly show that this border should be shifted to the east of Lena River delta. Our data thus finalize the debate over the species status of L. bungei. The specimens from the terra typica of this form fall within the western phylogroup forming a subclade.

The data of sequencing of samples from the mouth of the Lena River presented here excellently supported our assumption (Abramson, 1999b, 2001) and finally resolved the question on the status of the bungei form. While shifting the main split in cyt $b$ in Palaearctic lemmings to the east of the Lena River mouth, there is no doubt that additional sampling will reveal mixed populations combining individuals of different clades, as there are no physical barriers for lemmings on this territory and they are distributed all over. So, the mitochondrial DNA splits in the given case reflect the processes of range fragmentation in the past and secondary contacts, but not the speciation process. Fossil remains of true lemmings are known from the Late Pliocene (approximately $3 \mathrm{Ma}$ ) and already by that time were widely distributed throughout Palaearctic (see review in Abramson, 1993). It should be underlined that proceeding from the morphological characteristics these rodents were always indicative first of all of humid environment rather than cold one, and periodical glacial advances of Pleistocene resulted in establishing on wide territory of Eurasia open landscape of the socalled tundra steppe, that was unfavorable for bogdwelling species and best fit species more adapted to cold and dry environment. It is possible to suppose that during glacial maximums the continual range of true lemmings contracted and was fragmented into several variably isolated refugia. The following interglacial periods led to range expansion and mixing of early isolated population and resulting in high genetic variation in most recent lemming population (Ehrich \& Jorde, 2005). The deep split into western and eastern groups of populations revealed in cyt $b$ cladogram may reflect this past isolation when the species range was shifted far to the south and Verkhoynskii Range most probably served a natural barrier to migration. With the destruction of the tundra-steppe zone and retreat of tundra to the high latitudes true lemmings shifted their distribu- 


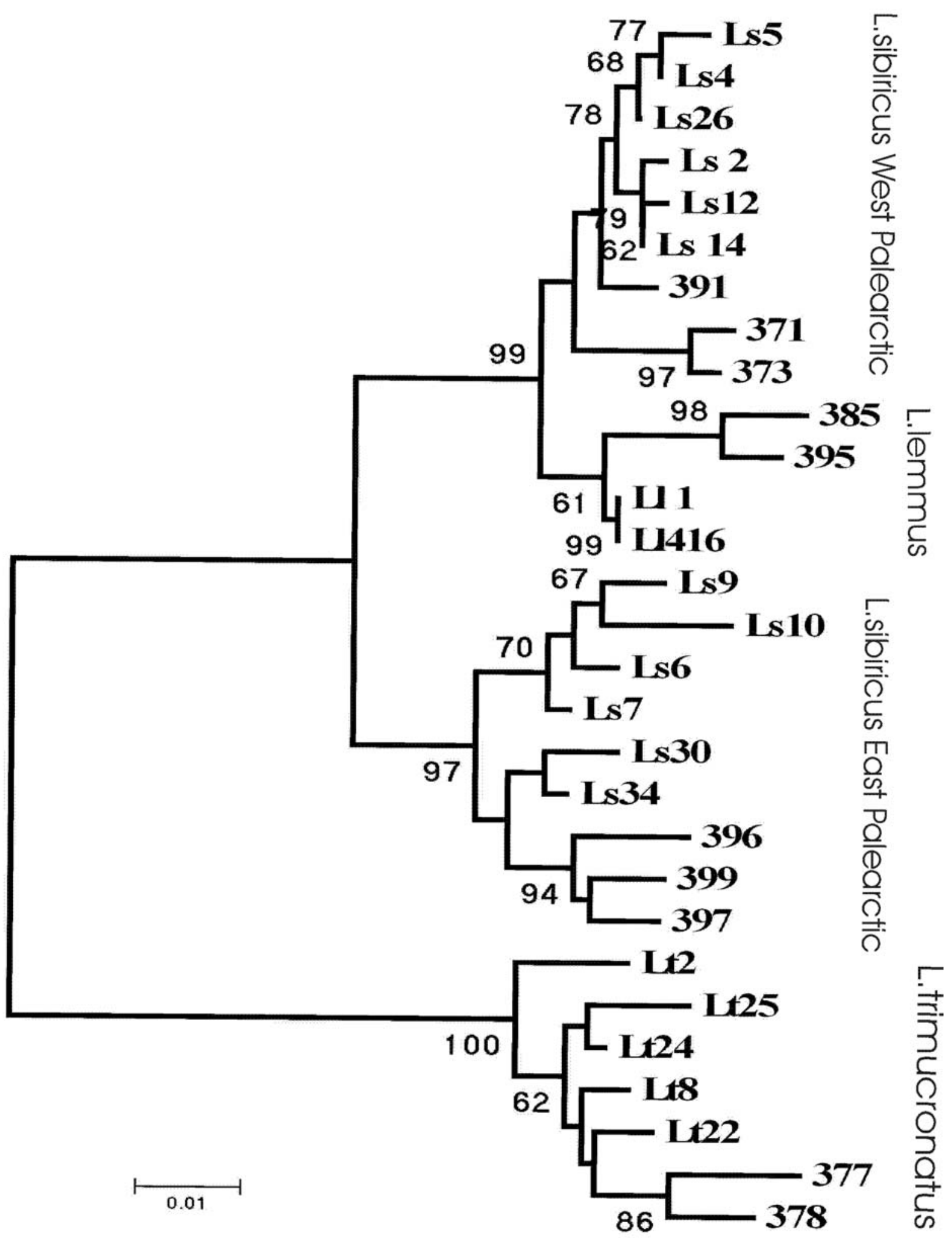

Figure 2. Neighbour-joining unrooted tree illustrating phylogenetic relationships among mtDNA haplotypes in Palaearctic Lemmus. The tree is based on the cyt $b$ sequence divergence estimates. Geographic origin of haplotypes are given in the Table1. Numbers to the left of the node stand for a bootstrap percentage from 1000 replicates. 
tion in accordance with the tundra zone and permafrost, therewith previously isolated populations appeared to be continuously distributed from the east coast of the White Sea to the west bank of the Kolyma River without any evident barrier to migration and mixing of population. Therefore, the observed deep split in $\mathrm{mtD}$ NA dividing lemmings into clusters of western and eastern populations does reflect events of past distribution history rather than the present day biodiversity and thus is irrelevant to the current taxonomy. However, lemmings inhabiting Fennoscandia (Lemmus lemmus) and those inhabiting tundra to the east of the White Sea, contrary to Siberian lemmings, are now well isolated and show definite diagnostic features in fur color, but the time of this isolation may not exceed 18000 years and quite logically we find this signature in significantly smaller genetic distance between these recognized species than between groups of continuously distributed Siberian populations. The study of nuclear molecular markers will most likely show incongruent results with mtDNA analysis. Several taxonomic decisions adequate to the up to day comprehensive knowledge of true lemmings could be adopted. If one makes choice in favor of stability of taxonomic system, what we in our turn consider to be a rather strong argument, then the current opinion recognizing four species (Jarell \& Fredga, 1993; Gromov \& Erbajeva, 1995; Pavlinov, 2006) will take over. The other decision which will emphasize the importance of reproductive criteria will be to distinguish only two species, L. lemmus and $L$. trimucronatus, while Amur and Siberian lemmings consider as subspecies (L. l. sibiricus and L. l. amurensis respectively). The most balanced decision best representing the evolutionary history of the group we see in reflecting in taxonomy the main split in true lemmings into Palaearctic and Nearctic stems by introducing the subgenus rank, and thus referring L. trimucronatus to one subgenus and three Palaearctic species: L. lemmus, L. sibiricus, L. amurensis to another. In our view, the optimal taxonomy of true lemmings, representing the evolutionary history of the group with the main split between Palaearctic and Nearctic lineages, would be one ranking L. trimucronatus and three Palaearctic species (L. lemmus, L. sibiricus, L. amurensis) as subgenera.

Alongside with always tangled and debatable taxonomy questions the example of this study rise and a number of more general issues on the possibilities and limitations of application of mitochondrial DNA markers and direct interpretations of mitochondrial DNA trees into species phylogenies and taxonomy. Molecular data and levels of divergence in the sequences of cyt $b$ undoubtedly allow us to reconstruct the plausible population history, processes of range fragmentations and secondary contacts, as well as historical demography. Molecular data have a number of clear advantages over morphological data, including hardly possibly parallel origin of identical haplotypes when the nucleotide variability of the marker is high enough, environmental neutrality of considered characters, and origination of certain geographic pattern of mitochondrial haplotypes as a result of long lasting barrier to the gene flow. However, despite the obvious value of mtDNA data, it is necessary to underline that their interpretation is frequently too straightforward, and direct taxonomic conclusions are often ridiculous (Abramson, 2007).

ACKNOWLEDGMENTS. Authors thank Drs. Love Dalen (Department of Zoology, Stokholm University), Nataliya Emel'chenko (Severtzov's Institute of Problems of Ecology and Evolution, Moscow), Evgeny Nikonorov (Kronottzkii State Reserve) for the supplied material on lemmings. This work was supported by the Russian Foundation for the Basic Research (project 03-04-49179), Program of Presidium RAS "Scientific Fundamentals of Biodiversity", Program of Presidium RAS "Dynamics of Plant, Animal and Human Gene Pools."

\section{References}

Abramson N.I. 1993. [The genus Lemmus in Eurasia in the Late Cenozoic] // Trudy Zoologicheskogo Instituta AN SSSR. T.249. P.146-157 [in Russian, with English summary].

Abramson N.I. 1999a. Morphometric variation in true lemmings (Lemmus) from the Eurasian Arctic // Ambio. Vol.28. No.3. P.256-260.

Abramson, N.I. 1999b. Taxonomy and zoogeography of true lemmings (Lemmus): Evidence from classical morphology and mtDNA variation data. // Proceedings of the Zoological Institute, Russian Academy of Sciences. Vol.281. P.9-14.

Abramson N.I. 2001. Taxonomy of Arctic lemmings: A review of current developments // Newsletter of International Breeding Conditions Survey. No.3. P.25-31.

Abramson N.I., 2007. [Phylogeography: Results, issues and perspectives] // Informatsionnyi Vestnik Vsesoyuznogo Obshchestva Genetikov i Selektsionerov. T.11. No.2. P.307-331 [in Russian, with English summary].

Chernyavskii F.B., Abramson N.I., Tsvetkova A.A., Anbinder E.M. \& Kurisheva L.P. 1993. On taxonomy and zoogeography of true lemmings of genus Lemmus (Rodentia, Cricetidae) of Beringia.// Zoologicheskii Zhurnal. Vol.72. No.8. P.111-112 [in Russian, with English summary].

Corbet G.B. \& Hill J.E. 1991. A World List of Mammalian Species. Third Edition. London \& Oxford: Natural History Museum Publications \& Oxford University Press. VIII $+243 \mathrm{p}$.

Corbet G.B., 1978. The Mammals of the Palaearcic Region: A Taxonomic Review. London \& Ithaca: British Museum (Natural History) \& Cornell University Press. 314 p.

Ehrich D. \& Jorde P.E. 2005. High genetic variability despite high-amplitude population cycles in lemmings // Journal of Mammology. Vol.86. No.2. P.380-385.

Fedorov V.B., Goropashnaya A.V., Jarell G.H. \& Fredga K. 1999. Phylogeographic structure and mitochondrial DNA diversity in true lemmings (Lemmus) from Eurasian Arctic // Biological Journal of the Linnean Society. Vol.66. No.3. P.357-371. 
Fedorov V.B. \& Stenseth N.C. 2001.Glacial survival of the Norwegian lemming (Lemmus lemmus) in Scandinavia: Inference from mitochondrial DNA variation // Proceedings of the Royal Society of London, Series B: Biological Sciences. Vol.268. No.1469. P.809-814.

Fedorov V.B., Goropashnaya A.V., Jaarola M. \& Cook J.A. 2003. Phylogeography of lemmings (Lemmus): No evidence for postglacial colonization of Arctic from the Beringian refugiums // Molecular Ecology. Vol.12. No.3. P.725-731.

Fredga K., Fedorov V., Jarell G. \& Jonsson L. 1999. Genetic diversity in Arctic lemmings // Ambio. Vol.28. No.3. P.261-269.

Gileva E.A., Kuznetsova I.A. \& Cheprakov M.I. 1984. [Chromosomne sets and taxonomy of true lemmings (genus Lemmus)] // Zoologicheskii Zhurnal. Vol.63. No.1. P.105-114 [in Russian, with English summary].

Gromov I.M. \& Erbaeva M.A. 1995. [The Mammals of Russia and Adjacent Territories. Lagomorphs and Rodents]. Sankt Peterburg: Zoologicheskii Institut RAN. 522 p. [in Russian].

Hendry A.P., Vamosi S.M., Latham S.J., Heilbuth J.C. \& Day T. 2000. Questioning species realities // Conservation Genetics. Vol.1 No.1. P.67-76.

Jarell G.H. \& Fredga K. 1993. How many kinds of lemmings? A taxonomic overview // Stenseth N.C. \& Ims R.A. (eds). The Biology of Lemmings. London: Academic Press. P.45-57.

Krivosheev V.G. \& Rossolimo O.L. 1966. [Intraspecific variability and taxonomy of Siberian lemming (Lemmus sibiricus Kerr, 1792) in the Palaearctic // Byulleten' Moskovskogo Obshchestva Ispytatelei Prirody, Otdel Biologicheskii. T.71. Vyp.1. P.5-17 [in Russian].

Kuznetsova I.A. 1995. Revision of Eurasian representatives of genus Lemmus Link, 1785 // Gurnell J. (ed). Second European Congress of Mammology. Abstracts. Southampton: Southampton University. P.46.

Musser G.G. \& Carleton M.D. 1993. Family Muridae // Wilson D.E. \& Reeder D.A. (eds.). Mammal Species of the World: A Taxonomic and Geographic Reference. Second Edition. Washington \& London: Smithsonian Institution Press. P.501-755.

Musser G.G. \& Carleton M.D. 2005. Superfamily Muroidea // Wilson D.E. \& Reeder D.M. (eds.). Mammal Species of the World: A Taxonomic and Geographic Reference. Third edition. Baltimore: The Johns Hopkins University Press. P.894-1531.

Nichols R. 2001. Gene trees and species trees are not the same // Trends of Ecology and Evolution. Vol.16. No.7. P.358-364.

Ognev S.I. 1948. Mammals of the USSR and Adjacent Territories. Vol.6. Moskva-Leningrad: Izdatel'stvo Akademii nauk SSSR. 559 p. [in Russian].

Pavlinov I.Ya. 2006. [Systematics of Recent Mammals. Second Edition]. Moskva: Izdatel'stvo Moskovskogo Universiteta. 297 p. [in Russian].

Pokrovskii A.V., Kuznetzova I.A. \& Cheprakov M.I. 1984. [Hybridological studies of reproductive isolation of Palaearctic species of genus Lemmus (Rodentia, Cricetidae)] // Zoologicheskii Zhurnal. Vol.63. No.6. P.904911 [in Russian, with English summary].

Rausch R.L. \& Rausch V.R. 1975. Taxonomy and zoogeography of Lemmus spp. (Rodentia: Arvicolinae), with notes on laboratory-reared lemmings // Zeitschrift für Säugetierkunde. Bd.40. Hf.1. P.8-34.

Saitou N. \& Nei M. 1987. The neighbor-joining method: A new method for reconstructing phylogenetic trees // Molecular Biology and Evolution. Vol.4. No.4. P.406-425.

Sambrook J., Fritch E.F. \& Maniatis T. 1989. Molecular Cloning: A Laboratory Manual. Second Edition. New York: Cold Spring Harbor Laboratory Press.

Shenbrot G.I. \& Krasnov B.R. 2005. An atlas of the geographic distribution of the arvicoline rodents of the world (Rodentia, Muridae: Arvicolinae) // Pensoft Series Faunistica. No 45. $336 \mathrm{p}$.

Sidorowicz J. 1964. Comparison of the morphology of representatives of the genus Lemmus Link, 1795, from Alaska and Palaearctic // Acta Theriologica. Vol.8. No.0. P.217225.

Tamura K, Dudley J., Nei M. \& Kumar S. 2007. MEGA4: Molecular Evolutionary Genetics Analysis (MEGA) software version 4.0// Molecular Biology and Evolution $10.1093 / \mathrm{molbev} / \mathrm{msm} 092$.

Vinogradov B.S. 1925. [Materials on taxonomy and morphology of rodents. III. Notes on Palaearctic lemmings (genus Lemmus)] // Ezhegodnik Zoologicheskogo Museya AN SSSR. T.26. P.51-73 [in Russian]. 